Article

\title{
Accuracy of Environmental Monitoring in China: Exploring the Influence of Institutional, Political and Ideological Factors
}

\author{
Daniele Brombal \\ Department of Asian and North African Studies, University Ca' Foscari Venice, 30123 Venice, Italy; \\ daniele.brombal@unive.it; Tel.: +39-041-234-9585 \\ Academic Editor: Marc A. Rosen \\ Received: 21 March 2016; Accepted: 5 December 2016; Published: 23 February 2017
}

\begin{abstract}
Environmental monitoring data are essential to informing decision-making processes relevant to the management of the environment. Their accuracy is therefore of extreme importance. The credibility of Chinese environmental data has been long questioned by domestic and foreign observers. This paper explores the potential impact of institutional, political, and ideological factors on the accuracy of China's environmental monitoring data. It contends that the bureaucratic incentive system, conflicting agency goals, particular interests, and ideological structures constitute potential sources of bias in processes of environmental monitoring in China. The current leadership has acknowledged the issue, implementing new measures to strengthen administrative coordination and reinforce the oversight of the central government over local authorities. However, the failure to address the deeper political roots of the problem and the ambivalence over the desirability of public participation to enhance transparency might jeopardize Beijing's strive for environmental data accuracy.
\end{abstract}

Keywords: China; environmental monitoring; accuracy; decision making; institutions; politics; ideology

All the questions had received splendidly drafted answers: answers not open to doubt, since they were not the result of human thoughts (always liable to error), but were the outcome of official labours. Lev Tolstoj, 1877 [1]

\section{Introduction}

Environmental monitoring aims to produce evidence that reveals the state of the environment based on continuous, long-term measurements of physical, chemical, and biological variables [2,3]. Environmental monitoring has an essential function in assisting decision-making processes by pinpointing new environmental problems, supporting the evaluation of environmental management policies, plans, and projects, and providing evidence for regulatory evolution [4]. Environmental monitoring is a key feature of environmental governance in virtually every country of the world [5]. Data accuracy, defined as the "closeness of agreement between a measured quantity value and a true quantity value of a measurand" ([6], p. 21), is a precondition for effective environmental monitoring [7]. The role of non-technical factors in undermining data and data-reporting accuracy in policy-oriented research is widely known. Under certain conditions, institutions and single individuals have the tendency to support certain outcomes over others, generating systematic errors, resulting from flaws in the procedures of sampling, data collection and processing. Reasons behind this may include conflicting institutional goals, political pressures, private interests, official discourses, and ideological structures expressing the fundamental beliefs of a group and its members $[4,8,9]$. The way these factors 
exert an influence on the process of environmental monitoring is highly context-specific. This paper investigates the institutional, political, and ideological factors affecting the accuracy of environmental monitoring in China. In recent years, the development of environmental monitoring has been at the core of Beijing's efforts for improving environmental governance, in line with the Scientific Outlook on Development (kexue fazhanguan) embraced by the Communist leadership a decade ago [10,11]. This official doctrine can be read through the lens of a greater reliance on scientific evidence to inform decision-making processes towards a more sustainable mode of development $[10,11]$. The very same concept of sustainable development is at the core of the concept of "ecological civilization" (shengtai wenming), introduced in 2007 and currently orienting much of China's environmental governance towards a re-balancing of the relationship between man and nature [12,13]. Considerable investments have been made to upgrade technologies: China's domestic environmental monitoring market has grown steadily in recent years, with sales of monitoring products surging from 1 billion RMB in 2006 to 5 billion in 2013 [14]. This trend is destined to continue in the near future, thanks to the planned increase in environmental protection investment during the 13th Five-Year Plan (2016-2020) [15-17]. At the regulatory level, environmental quality standards have been revised and improved $[18,19]$. However, the structure of the official monitoring system has remained largely modelled after the country's administrative structure, with ministries and their affiliated agencies still providing the bulk of data and reports. This reproduces inter- and intra-provincial differences in terms of environmental protection system efficiency, including long-standing issues of lack of trained personnel in poorer regions [20,21]. Against this background, efforts have been made to improve coordination among government agencies and to strengthen the vertical management of local environmental protection bodies [22,23]. A sign of the importance attributed by Beijing to tightening the control over local authorities is provided by the establishment of "environmental supervision talks" (EST; huanjing duzheng yuetan) in 2007. The EST mechanism consists of administrative talks held by officials of the Ministry of Environmental Protection (MEP) in localities where concerns have been raised over environmental quality and over the capacity of local authorities to meet environmental standards. Significantly, rather than through local Environmental Protection Bureaus (EPBs), the EST mechanism is directly operated by the MEP through six ad-hoc Regional Supervision Centres (RSC) [24,25]. Cooperation between the government, universities and research institutes has increased as well. Tenders for environmental and policy-oriented research services are regularly launched by national and provincial authorities, under various financing schemes. New Key-State Laboratories hosted by ministry-affiliated agencies and universities have been established with government funding. Many of them conduct environmental monitoring in specific geographical areas and/or targeting particular issues [26]. Civil society organizations and foreign institutions have entered the field as well, although their interaction with the bureaucracy remains somehow limited. Despite political commitment, investments, and regulatory and organizational progress, the accuracy of Chinese official environmental data is still contested by both domestic and foreign observers. This is a by-product of several factors, including the establishment of public disclosure mechanisms, the growth of social media, and the accessibility of third party sources of information. Under mounting pressure from the domestic public and the media, authorities have acknowledged problems affecting the quality of data. High-ranking officials and government spokesmen tend to blame these problems on issues historically affecting the country, such as the poor coordination among monitoring agencies, diverging interests between central and local authorities, and corruption [27-29]. Beijing has committed to implement organizational and administrative measures fighting data manipulation, i.e., the behaviour of not reporting the true pollution level, either by falsifying or hiding pollution data (for a definition of 'manipulation', cf. [7], p. 204) However, as we will discuss further on in this paper, focusing on organizational issues and corruption alone might lead to an oversimplification of the problem, which in fact has deeper political and ideological roots, with wide implications for environmental governance. 


\section{Structure and Methods}

The paper is divided into four parts. The third section introduces discrepancies in Chinese environmental monitoring results, providing the rationale for concerns about the accuracy of official monitoring data. The section reviews scientific and grey literature, as well as media reports introducing cases relevant to air, water, and soil pollution. Discrepancies are individuated by comparing data reported by government institutions, research institutes, and foreign agencies. Whenever possible, data referring to the same parameter, geographical area, and time-span are introduced, in order to allow for a direct comparison between results reported by different sources. The discrepancies highlighted in this section do not permit a definition of the nature, extent and source of inaccuracy, nor do they provide conclusive evidence on the existence of manipulation. However, they can be considered as suggestive of the presence of biases generated by the political and social environment [30-34]. More importantly, they closely relate to concerns expressed by many among the Chinese public over the "truthfulness" of environmental data reported by Chinese authorities. As such, cases introduced in the third section aim at presenting a qualitative description of issues that are commonly observed in Chinese environmental monitoring and of the related public debate. On this basis, the fourth section introduces possible non-technical causes of bias in environmental monitoring. The characterization of these non-technical factors is carried out by triangulating scientific literature, grey literature, and semi-structured interviews carried out in the field between 2012 and 2015. The following categories are discussed: (1) Bureaucratic incentives; (2) Institutional goals; (3) Private interests; (4) Interactions between public and private interests; and (5) Ideology and political culture. The fifth section discusses findings vis-à-vis the current trends of development of Chinese environmental governance. The concept of "fragmented authoritarianism" is proposed as an analytical tool to systematize the understanding of institutional, political, and ideological factors impacting on environmental data accuracy. The notion of fragmented authoritarianism was first coined by political scientists in the 1980s, to describe a polity where, in spite of its authoritarian features, substantial bargaining processes occur among different bureaucracies, greatly influencing policy outcomes [35,36]. In recent years, the notion was expanded to embrace other actors (public and private), who, by taking advantage of windows of opportunity, act to generate political change [37]. The concept of fragmented authoritarianism is particularly suited to grasp the nature of centrifugal and centripetal political processes potentially influencing the accuracy of environmental monitoring. Finally, the sixth and conclusive paragraph summarizes progress made and challenges ahead in the field of environmental monitoring in China.

\section{Environmental Monitoring Data in China: Discrepancies and Concerns over Accuracy}

\subsection{Air Pollution}

The most notorious case raising concerns over the accuracy of Chinese environmental monitoring is the querelle over air quality data in Beijing. Attention was first drawn to it during preparations for the Olympics (held in 2008), when local authorities reported a marked improvement in air quality [38]. In 2007, the number of days reaching the national standard, called "blue sky" days, reportedly reached 246, compared to 100 in 1998. "Blue sky" days were then defined as those with particulate matter $10\left(\mathrm{PM}_{10}\right)$ levels $\leq 150 \mu \mathrm{g} / \mathrm{m}^{3}$, i.e., within the threshold of air quality Grade II, which delimits in urban areas air with acceptable quality. In a work published in the peer reviewed journal Environmental Research Letters in 2008, Beijing-based environmental analyst Steven Andrews claimed that improvements in Beijing air quality had been fabricated by authorities, by changing monitoring stations locations and removing stations in the most polluted areas [38]. A few years later, between 2011 and 2012, a public debate erupted around discrepancies between air quality data provided by the municipal government and the U.S. Embassy in Beijing. According to domestic and international media reports, $\mathrm{PM}_{2.5}$ data produced by the U.S. Embassy were higher than $\mathrm{PM}_{10}$ data recorded by the government monitoring stations closest to the location of the embassy [39]. Since $\mathrm{PM}_{2.5}$ is a subset of $\mathrm{PM}_{10}$ (its values should therefore be lower than those of $\mathrm{PM}_{10}[40,41]$ ), the difference 
caused scepticism over official $\mathrm{PM}_{10}$ reporting, although no conclusive evidence could be produced in this regard, due to the different position of monitoring stations [39]. The domestic media kept a keen eye on the issue also after the competent authorities made $\mathrm{PM}_{2.5}$ readings available [42,43]. Differences can also be observed by comparing Beijing official data with those collected by other institutions. A study published in 2009 by Wang et al. shows a significant difference between self-measured and published $\mathrm{PM}_{10}$ values. In the period considered in their study (28 July-7 October 2008), they found that self-measured data were 1.3 times higher than official measurements [44]. The authors however state that this difference was "likely due" to different measurement methods used ([44], p. 5315). The case of Beijing is not isolated. In Xi'an, the capital of Shaanxi province, data released by the government have been subject to public scrutiny as well. In 2012, the online media outlet Xibuwang, controlled by the provincial government of Shaanxi, published an article on the "battle between officials and society over blue skies data in Xi'an" [45,46]. The article soon gained visibility on the internet, being republished both in generalist media outlets (among which the popular Sina.com) and in websites affiliated with the MEP. The piece cited an extensive study (1765 observations) conducted by the Institute of Earth Environment of the Chinese Academy of Sciences (CAS) between 2004 and 2008, "representative of the general status of $\mathrm{PM}_{2.5}$ pollution in Xi'an" ([41], p. 374). Results of the study showed average annual concentrations of $\mathrm{PM}_{2.5}$ between $179.08 \mu \mathrm{g} / \mathrm{m}^{3}$ and $206.78 \mu \mathrm{g} / \mathrm{m}^{3}$ [45]. Since $\mathrm{Xi}^{\prime}$ an authorities had not yet began officially monitoring $\mathrm{PM}_{2.5}$, the Xibuwang's article did not compare CAS data with official ones. It nonetheless raised doubts over the credibility of local government's reporting on the number of days with good quality. Indeed, CAS findings appeared to be at odds with official reports, which in 2007 and 2008 credited the city with over the $80 \%$ of days with good quality air, within the daily threshold of air quality Grade II (daily $\mathrm{PM}_{10} \leq 150 \mu \mathrm{g} / \mathrm{m}^{3}$ ) [47,48]. As a matter of fact, official data allowing for a direct comparison of $\mathrm{PM}_{2.5}$ concentrations in $\mathrm{Xi}^{\prime}$ an had been previously included in an MEP document. The 2010 MEP explanatory notes for the interim version of the revised Ambient Air Quality Standard (GB 3095-2012) include a summary table of $\mathrm{PM}_{2.5}$ for selected cities [49] (p. 22). For Xi' an, the average annual data $\mathrm{PM}_{2.5}$ concentration reported for 2008 was between 55 and $60 \mu \mathrm{g} / \mathrm{m}^{3}$. As can be seen in Figure 1, these concentrations are a mere one-third of those reported by CAS for 2008, as well as for the entire period of 2004-2008 [41,45,49].

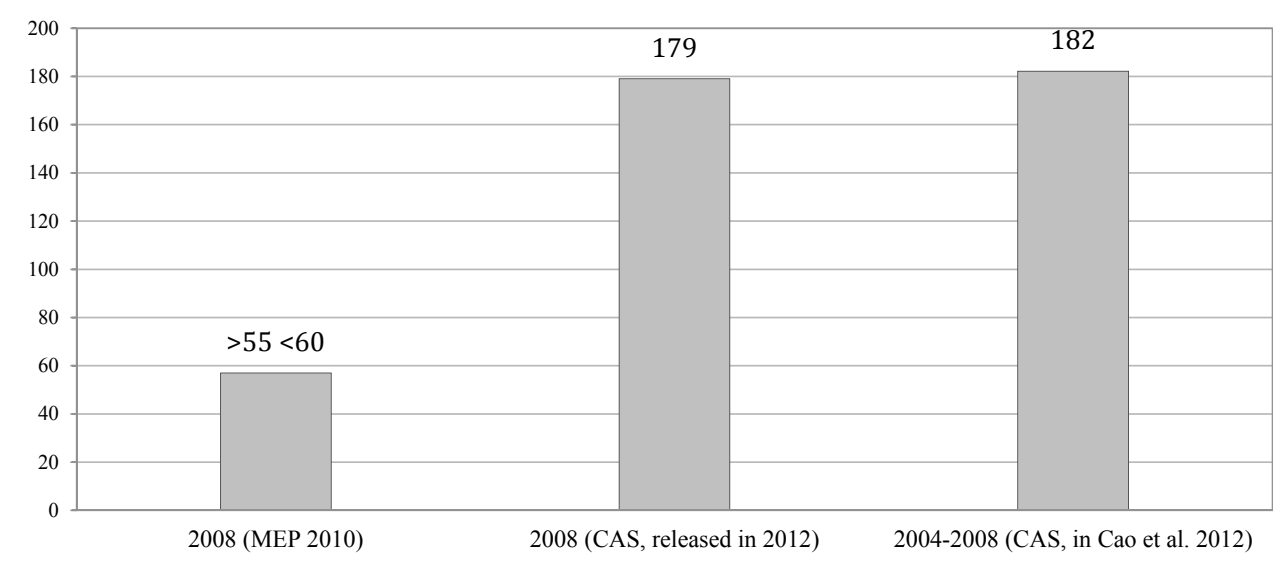

Figure 1. Xi'an, Shaanxi province. Average annual concentrations of $\mathrm{PM}_{2.5}\left(\mu \mathrm{g} / \mathrm{m}^{3}\right)$.

Data included in the MEP report are slightly lower than average concentrations reported for 2009 by another independent study, representative of the suburbs (jiaoqu) of Xi'an. This study reports a value of $\mathrm{PM}_{2.5}$ of $75.8 \mu \mathrm{g} / \mathrm{m}^{3}$ [50]. As in the case of Beijing, also in Xi'an local officials dismissed scepticism about local government reports by stating that "single monitoring station[s] [ ... ] are not representative of the entire [city]" ([45], online. On China's air pollutants emissions at national level, see $[51,52])$. 


\subsection{Water}

The case of Huaihe River is particularly poignant in exposing discrepancies in water environmental quality monitoring. One of the most polluted rivers of the country, the Huaihe flows through Henan, Anhui, and Jiangsu provinces in Eastern China. Since the late 1990s, its basin has been targeted by initiatives to promote watershed-based management [53]. Integrated measures for environmental pollution control have been piloted and environmental monitoring strengthened. Notwithstanding these efforts, data reported by the State Administration for Environmental Protection (SEPA, since 2008 MEP) and the Ministry of Water Resources (MWR) often presented sensible discrepancies, as can be seen in Figure 2 [53,54]. Similar issues can be found among data reported by the very same agency. The Huaihe Environment Report 2000 and the Tenth Five-Year Plan for Water Pollution Prevention and Control, both drafted by SEPA, provide diverging assessments of water quality. Figures related to water graded $\mathrm{V}$ and above—indicating the worst water quality—ranged from $45.2 \%$ to $72.7 \%$ (Figure 3) [54].

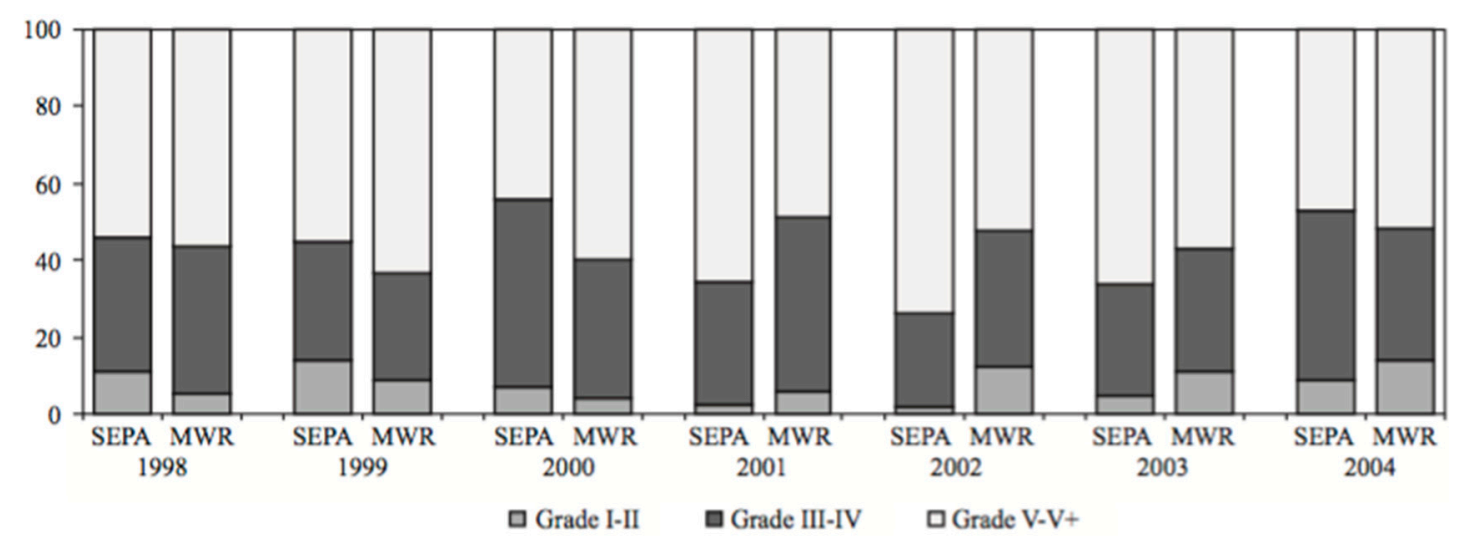

Figure 2. Huaihe River water quality, 1998-2004 (percent). SEPA: State Administration for Environmental Protection; MWR: Ministry of Water Resources.

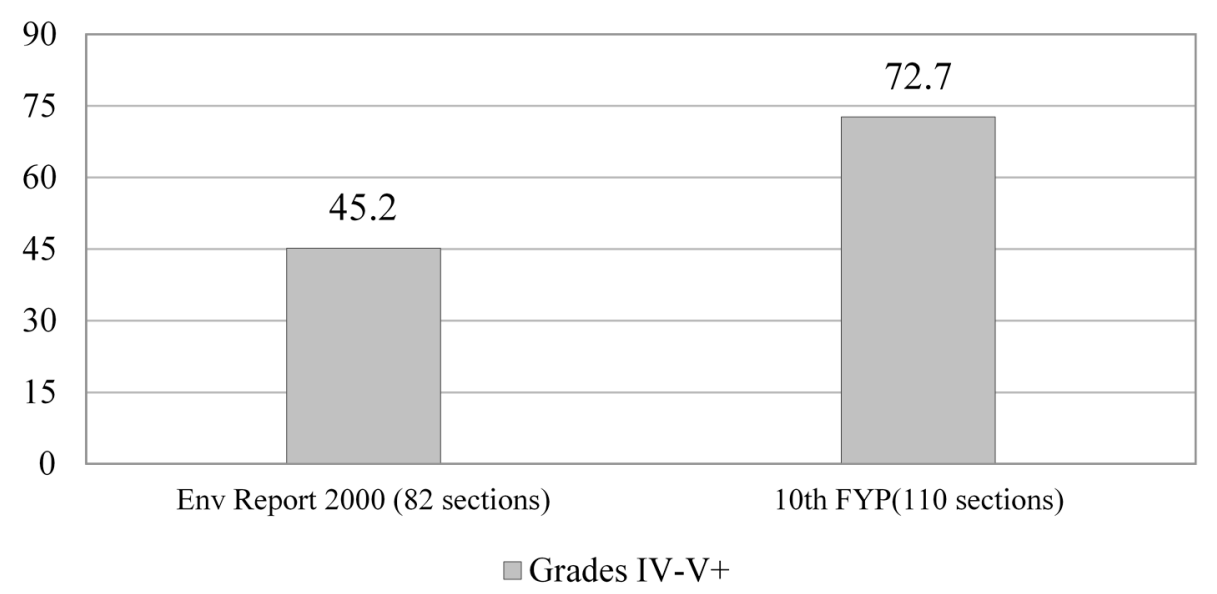

Figure 3. Huaihe River water quality, 2000 (percent). FYP: Five-Year Plan.

The issue of data discrepancies among government sources is not limited to surface waters. In 2014-2015, contradictory data on the quality of drinking water sources (mostly underground water) were divulged by the MEP, MWR, and the Ministry of Land Resources (MLR), which all bear responsibilities in terms of environmental monitoring [55]. Discrepancies between data provided by different agencies have also been found in the case of heavy metals transported by rivers to the sea. In 2011, data on lead and arsenic reported by the MEP and the State Oceanic Administration (SOA) greatly differed, as shown in Figure 4 [56-58]. 


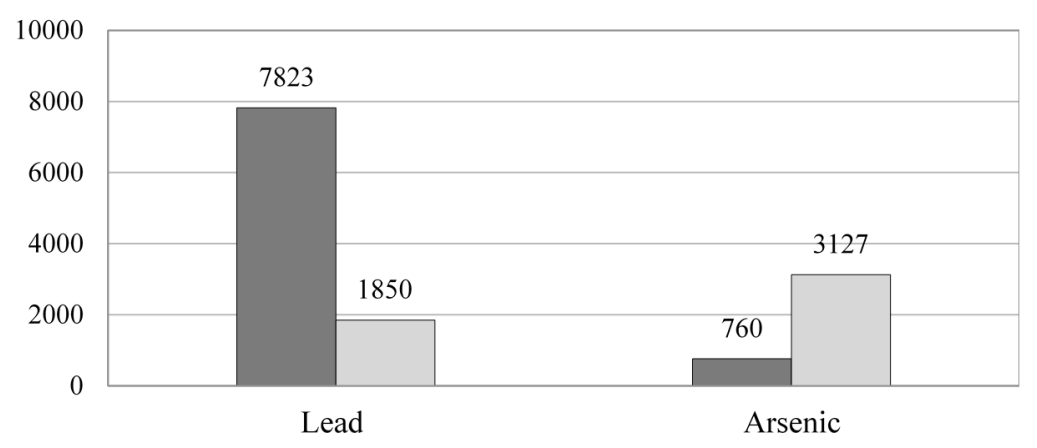

Figure 4. Selected heavy metals carried by rivers to the sea in 2011 (Tonnes).

Wastewater treatment is similarly characterized by contradictory assessments. Information released by the Ministry of Housing and Urban Rural Development (MoHURD) has been questioned. According to an official statement recently made by MoHURD, by 2011, 83.4\% of the water leaving treatment facilities met official standards, a marked improvement from the 58.2\% reported in 2009 [59,60]. However, this estimate was contradicted by Song Lanhe, a scientist employed by MoHURD, who released interviews denying that any improvement had been made since $2009[59,60]$.

\subsection{Soil}

Compared with air and water pollution, the attention devoted to soil pollution is more recent in China [18]. Nonetheless, the first National Soil Pollution Survey allows to put forward a few considerations regarding data accuracy. The survey, conducted by the MEP and the Ministry of Land and Resources (MLR) between 2006 and 2010, was a major effort to assess the quality of soil in China. Conducted on a total surface of $6,300,000 \mathrm{~km}^{2}$ (65.6\% of the national total surface), it reportedly covered all arable lands in the country, targeting 690 industrial sites, 81 abandoned industrial sites, 146 industrial parks, 188 solid waste processing venues, 13 oil producing districts, 70 mining areas, 55 sewage irrigation areas, and road-side soils of 267 major roads [18]. Access to the survey's findings was granted to the public only in April 2014, after a long debate engaging relevant bureaucracies [61]. Just one year before the survey was made public, the MEP had refused to release the results, stating that they had to be considered a state secret. This occurred after the lawyer and environmental activist Dong Zhengwei had sent a request to the MEP to publish the data. This triggered a public debate involving well-known activists such as Ma Jun, head of the Institute of Public and Environmental Affairs [61]. It is not yet known to what extent the public and the media contributed to the subsequent release of the survey. The media-even official ones-concurred on the fact that initial resistance by the MEP was caused by the sensitive nature of data and by the fact that findings highlighted a situation worse than that expected [61]. In this regard, speculations have arisen on the possible manipulation of results. Data show that the overall rate of polluted soil is $16.1 \%$, with slightly, mildly, moderately and severely polluted soils accounting respectively for the $11.2 \%, 2.3 \%, 1.5 \%$ and $1.1 \%$ of the total. According to the survey, the soil quality of $19.4 \%$ of arable land does not reach national environmental quality standards [18]. In heavily polluted industrial sites, soil quality does not reach the national standard in $36.3 \%$ of cases [18]. In mining areas, $33.4 \%$ of soils do not meet national requirements [18]. At present, disaggregated data of the survey are not accessible. It is therefore not possible to compare them with third party sources. However, by looking at other pieces of research, it is still possible to note some discrepancies. With reference to agricultural soils, the percentage of 19.4 of arable land not meeting soil standards is close to data from a survey conducted by the MEP in 2011, targeting 364 villages, in which $21.5 \%$ of samples did not meet quality standards [62]. The claim that $1.1 \%$ of total soils were severely polluted appears to be at odds with other findings. According to a study carried out by Wei and Yang between 2007 and 2009 on a sample of 20 cities, "urban soils in the cities from China have been significantly influenced by the heavy metals derived from anthropogenic 
activities [ ... ] Approximately $65 \%$ of all the cities have high or extremely high contamination levels of heavy metals in urban soils and urban road dusts" [63]. The non-profit organization Changsha Shuguang Environmental Charity Development Centre reports that in the soils of 10 cities along Xiang River (Hunan province) concentrations of heavy metals exceeding 1500 times the permitted levels have been found in recent years [64] (on contaminated sites, see also [65]).

\section{Non-Technical Factors Influencing Data Accuracy}

It is not possible to attribute discrepancies introduced in the previous section exclusively to non-technical factors. In fact, these discrepancies could have been caused by different methods of data collection and analysis, different locations in monitoring stations, etc. However, two facts constitute a legitimate reason of concern over the existence of data manipulation. Firstly, official monitoring data often appear to underestimate environmental issues when compared with those produced by other sources. Second, criticism is not only exogenous to China, but much of it rather comes from domestic scientists, employed by state agencies and affiliated institutes. Their critiques cannot be simply dismissed as an attempt to discredit China or its leadership (see e.g., [66]). The issue therefore deserves an in-depth analysis of possible sources of bias in Chinese government monitoring systems. In this section, the following factors are discussed: bureaucratic incentives, institutional goals, private interests and their interaction with public ones, and ideology.

\subsection{Bureaucratic Incentives}

Chinese officials' career advancements largely depend on a performance evaluation system controlled by the Party-State. The link between "good" data and the chance of cadres to be promoted is well described by the Chinese saying shuzi chu guan, which can be roughly translated as "the numbers make the official". Against this background, Chinese officials have historically considered the production of local statistics as highly sensitive, since it can exert a decisive impact on their economic, social, and political status. As political scientist Lily Tsai notes, "survey research itself is politically sensitive in China [ ... ] can be often used as a measure of the performance of particular officials and local governments" ([67], p. 249). Cai Yongshun finds that the pursuit of private interests by local officials is a common factor leading to manipulation of statistics [68]. For much of the "reform-and-opening-up" era-started in 1978-the chances of cadres to be promoted have been consistently focused on economic performance. As such, manipulation has been occurring frequently in this sector. In 2013, the U.S.-China Economic and Security Review Commission warned against manipulations and omissions in China's economic statistical reporting [69]. In recent years the criteria for the evaluation of officials evolved to also include environmental management. The process started in the early 2000s by establishing targets for air environmental protection in Chinese cities. It gained momentum during the Hu-Wen Administration (2002-2012), when the Scientific Outlook on Development became the ideological cornerstone of the Chinese model of development [10,11,27]. The introduction of the concept of "ecological civilization" (shengtai wenming) in 2007 reinforced this pattern by strengthening the claim that sustainability should play a vital role in shaping major policies of the country $[13,22]$. Changes in ideology have been accompanied by the introduction of a wider range of environmental targets in socio-economic planning and by innovations in the evaluation system of government officials $[70,71]$. The latter are now held accountable for the status of the natural environment in areas under their jurisdiction and incentivized to promote models of growth in line with the protection of the environment and society [71-74]. While these innovations represent a step forward towards a more sustainable pattern of development, in part they might produce the unintended consequence of incentivizing data manipulation. A confirmation to this hypothesis is provided by the work of Chen et al., who in 2013 published a paper titled "Gaming in Air Pollution Data? Lessons from China". The paper investigates the correlation between the reported air quality data in 37 Chinese cities and the introduction in 2003 of the target of "blue sky" for the evaluation of cities [40]. Authors find a significant discontinuity in the distribution of data at the "blue sky" 
threshold in officially reported Air Pollution Indexes (API). More interestingly, discontinuities are more pronounced in the period following the introduction of the above-mentioned "blue sky" target, suggesting data manipulation around the relevant threshold (100 API; $150 \mathrm{PM}_{10}$ ), as shown in the Figure 5 [40]. In an article published in 2014, Ghanem and Zhang further probe into the manipulation of air quality data at the city level, based on a dataset on air pollution data covering 113 cities for the period between 2001 and 2010. In about $50 \%$ of cases analysed, cities reported dubious $\mathrm{PM}_{10}$ levels, with discontinuities at the "blue sky" target cut-off. The authors conclude that this provides "suggestive evidence" of manipulation, which may occur "during the process of calculating daily average pollutant concentrations at station or city level" ([7], p. 210).

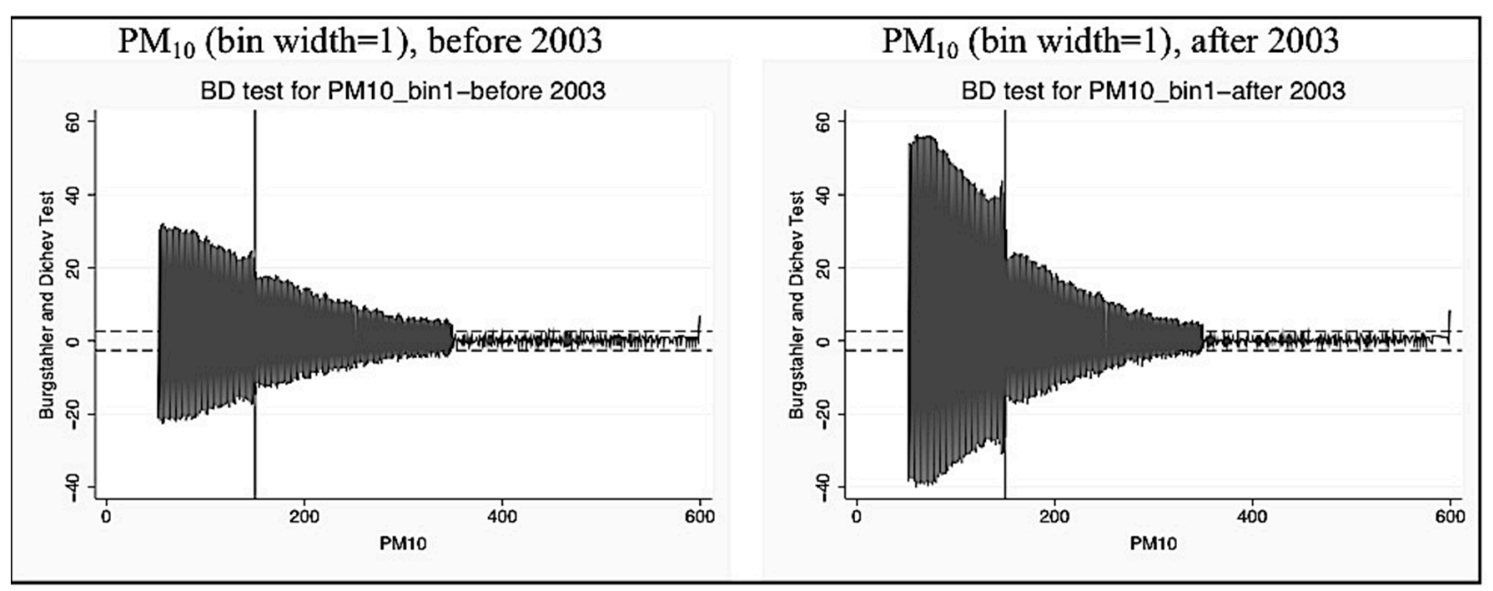

Figure 5. Distribution of reported air quality data in 37 Chinese cities, 2003 (original from Chen et al. [33], p. 18).

\subsection{Institutional Goals}

The fragmented nature of China's bureaucratic system has been debated since the 1980s, and it still hampers effective environmental management $[18,19,28]$. Agencies responsible for environmental management at the local level (including EPBs) depend on local governments for financial support [75]. They are therefore exposed to the interference of local officials, particularly when goals of environmental protection conflict with targets of economic development [76]. The phenomenon is often framed in terms of "local protectionism" (difang baohu zhuyi), i.e., the tendency of local governments to prioritize local economic interests over national concerns [77]. The issue is among the top priorities of Beijing's on-going attempt to reform the environmental protection system. In a statement released in January 2016, MEP officials defined the interference of local governments and their forging of "fake data" as "intolerable" [78]. Another long-standing problem is the horizontal fragmentation among agencies responsible for environmental management. The issue is of particular concern in the water sector, where at least 13 agencies have administrative responsibilities. These agencies often bear different interests. In particular, conflicts between the MWR and the MEP have occurred in cases when they have individuated different priorities in terms of water management [19]. Such conflicts may lead to diverging assessments of water quality. According to a researcher employed by a Chinese government institution, "looking at data on waste water treatment, it is clear that discrepancies are due to the fact that every different dataset is produced by different departments, with different interests [ ... ] You can say that each dataset reflects a particular interest" [79]. Where most of government stakeholders-both central and local—tend to agree is on the goal of maintaining social stability, in order to preserve the political status quo. This often results in a restrained access to the field and to information. According to a senior Chinese researcher:

When we try to investigate soil pollution we often have difficulties in accessing the field. Recently, we have found significant obstacles in a case study site [in Southern China]. We had already been there 
and found evidence of heavy metal pollution that was causing harm to the people's health. The local authorities are scared that if we go there again the people might notice that there's something wrong [with soil pollution] and get angry [80].

Things are more sensitive when it comes to gathering public views over environmental degradation. According to the experience of another researcher, local EPBs do not welcome public survey activities, simply "because they are afraid of [ ... ] social disorder", caused by "long-term discontent and anger in the hearts of the local people, because of environmental problems" [81]. On its part, the central government seems to be trapped in the contradiction between the commitment to protect the environment and people's health on one side, and on the other the fear that popular discontent might erupt if the extent of environmental issues is fully disclosed. Remarkable progress has been made in terms of information disclosure in the last decade. However, among Chinese authorities there still remains ambivalence over the desirability of greater public engagement [82]. The words of an official employed by a central department of the Communist Party of China (CPC) are revealing in this regard: "All this flow of information freely circulating, all these people saying what they feel like: it's extremely scary!" [83]. Strategies to avoid this gridlock range from education to censorship. During a conference held in 2012, an MEP high-ranking official bluntly described the need to guide the masses towards a better understanding of environmental issues: "Of course disclosure of environmental information is good. However, now you see that every kind of information is provided by media. We must educate the journalists and the public to distinguish between good and bad information" [84]. Censorship still occurs when information is perceived to be too sensitive as, at least initially, in the case of the first National Soil Pollution Survey, or when reports expose the inaccuracy of official data. This seems to have been the case for a research study conducted by Greenpeace and Peking University, according to which average daily measurements of $\mathrm{PM}_{2.5}$ in Beijing in 2014 were underestimated by an approximate 15\% [85]. Reports on the research published online in Chinese language by Caijing (one of China's leading magazines) were soon removed, while one version remained accessible on the online media outlet News.163. Similarly, in early 2015 the documentary on China's air pollution "Under the Dome" (Wanding zhi xia), produced by former TV journalist Chai Jing, was soon removed from the sharing site Youku after being posted; it did, however, remain available on YouTube, whose website is blocked in China [86].

\subsection{Private Interests}

Pressures leading to manipulation of-and restricted access to-environmental data and information can be based on economic interests as well. Many data used in environmental monitoring reports are provided by companies, either private or state-owned. Data are then collated by local EPBs. A government official cited in a 2014 World Bank report lists three common issues with this self-reporting system: luanbao, or "messy data that lacks logic"; manbao, i.e., "underreporting"; and tuobao, meaning "delay reports" [87]. In order to avoid the payment of emission charges and pollution fines, to cover-up environmental damages, and to underestimate data on production (in order to pay less taxes), companies have an interest in underreporting pollutant emissions and energy consumption [87-90]. The issue is not new: It rather traces back to 1990s, when according to a former environmental journalist, "all sorts of things were going on, and none of them was duly reported. All information [on companies polluting the environment] were either covered-up, or false. I'm sure this is the situation even today" [91]. According to a practitioner employed by a government affiliated institute,

For companies, the smaller is the extent of problems revealed by environmental data, the smaller is the likelihood of facing issues in terms of social responsibility and discharge fees. Even Environmental Protection Bureaus are also sceptical of these data [because] Chinese companies have an unwritten tradition of concealing [ ... ] data to avoid paying more taxes and sewage charges. Most of data from enterprises are clearly unreal. Data about emissions on $\mathrm{SO}_{2}$ and $\mathrm{NOx}$ according to 
national regulation should be provided [by companies] to Environmental Protection Bureaus, but in reality they often refuse and the regulation is not enforced. The problem is that Environmental Protection Bureaus usually don't collect data independently, as such there is no third-party oversight, and companies are free to hide environmental issues [92].

Restrictions also apply to fieldwork investigations, often carried out by the government and its affiliated institutions in order to crosscheck company environmental records (on inspections, see [87]). According to the same practitioner:

In one case, in a meeting with company employees during a field investigation, when several researchers questioned the discrepancies of data reported in documents provided by the company, the managers and their employees became very tense, immediately asked to collect back the materials [and] promised to give back the correct data [... I In [another] case the researchers asked to visit a company, but instead they were shown around the industrial park. When they asked to visit the places where environmental problems were most severe, the requests were politely rejected for various reasons [92].

These phenomena are not at all peculiar to the Chinese context alone. However, it appears that in China they are particularly severe and common. This is due to both the economic structure of the country, and the linkages between the industry and the bureaucracy. State-owned-enterprises (SOEs) still constitute the bulk of strategic —and highly polluting — sectors. Large SOEs are given a rank within the bureaucratic system of China, which is higher than the one of local environmental authorities: they report directly to the State-owned Assets Supervision and Administration Commission (SASAC), a ministry-level body directly under the State Council [93]. As such, they appear to be rather insulated from the administrative requests periodically submitted to them by EPBs [94].

\subsection{Interactions between Public and Private Interests}

Economy [94], in describing the challenges encountered by central authorities in producing accurate environmental assessments, points out the negative impact of "personal ties [guanxi] between local officials and enterprise managers" ([94], p.117). Such ties have developed, as mentioned above, in a context characterized by phenomena of local protectionism, particularly in areas where local economies depend on polluting activities [77]. In this context, the so-called "revolving-doors" system, where members of the Chinese élite can move back and forth from a career in the government to leading roles in SOEs, may disincentive officials from pursuing an accurate monitoring of environmental damage and pollutant emissions caused by companies (on the revolving doors system, see [95]). Big infrastructural projects are another instance in which, due to economic interests at stake, manipulation of environmental reporting can occur. According to a researcher employed by a governmental research institution, interviewed by the author in 2013,

When we drafted the report concerning the environmental risks posed by [a major hydro-power project] [ ... ] and submitted it for comments to our local partner [which had commissioned the study], its representatives told us that the report was too negative, and asked us to modify it to make it appear 'better'. We reported this suggestion back to our leaders, who later gave us the go-ahead to modify the report according to our partner's suggestion [96].

The issue is not confined to the interaction between governments, EPBs, and companies. Activities of environmental monitoring and assessment informing decision-making processes are often entrusted to licensed entities, which may include both government affiliated institutes and private companies. The case of the Environmental Impact Assessment (EIA) system, one of the main tools of environmental planning, is revealing in this regard (on the EIA framework, see [97]). The issue here is twofold: Firstly, environmental authorities often lack the capacity to effectively oversee the environmental data produced by licensed entities, due to the chronic shortage of funds, manpower, and equipment. As put by a Chinese practitioner with reference to the field of soil remediation, "it would be difficult 
for local EPBs staff to challenge the data [ ... ] by companies. Very often, the EPBs don't have the equipment or funds to make their own analysis of samples. Moreover, they would not take the risk of confronting the judgment of the experts employed by the company(ies)" [98]. Secondly, many qualified assessors working for licensed entities are at the same time civil servants, employed by environmental protection administrative bodies, or their affiliated research institutions. This is a reason for concern about potential conflicts of interest in the evaluation of EIA reports by competent authorities $[99,100]$. The accuracy of EIA reports is under close scrutiny by central authorities [100]. In 2015, the MEP found 15 companies guilty of producing fraudulent environmental impact assessments [100].

\subsection{Ideology and Political Culture}

Phenomena described in previous sub-paragraphs play within a wider ideological and socio-cultural context. This context is largely informed by the legacy of the 19th century, when the introduction of modern science and western political institutions in China coincided with the aggression of foreign powers [101]. Historically, science and technology have been interpreted by China's elite as instruments to serve national interests. With the exception of the years of the Cultural Revolution (1966-1976), this legacy can be traced throughout the 19th century in China: Regardless of the nature of the political regime-late imperial, republican, nationalist, or communist-the country's rulers have attributed great importance to science and technology to strengthen state authority and to achieve strategic goals of development $[102,103]$ (on the recent debate on the role of science and technology in China, see [104]). Since the late 1970s, through the Four Modernizations, science and technology have become an integral part of the CPC's political discourse, complementing an ideological structure whose credibility had been undermined by the Cultural Revolution [105]. As Susan Greenhalgh writes in her volume Just One Child. Science and Policy in Deng's China, in the late 1970s "modern science appeared as the way out, a deus ex machina that would guide China into the modern world [ ... ] post-Mao years would thus give rise to the rapid development not only of science, but also of scientism, the belief in science as a panacea that could solve all the nation's problems" [105]. The faith in science as an instrument to solve the country's problems and ensuring the capacity of the Party-State to retain its authority over society has been accompanied by an increasing reliance on "scientific decision making" (kexue juece). Seen in this light, the adoption of the concept of Scientific Outlook on Development (kexue fazhan guan) in the last decade constitutes the ideal conclusion of a path that attributes scientific connotations to the leading ideological structure. As already noted in Section 4.1, the concept of ecological civilization can be interpreted consistently with the scientific principles of sustainable development, albeit providing them with a cultural connotation peculiar to China's Confucian legacy. In fact, the concept itself of Scientific Outlook on Development is rather confusing to eyes not accustomed to reading through the lines of the Chinese political language. The misunderstanding-extremely common among foreign observers-is epitomized in the words of a promising young environmental scientist from Europe, after just a few days in China:

I already love this place. I really do. These days I've been reading news reports talking about China's scientific development policies. I think this is really wonderful: where else in the world policy makers put science above everything else? [106]

The misunderstanding lies in the fact that when Chinese leaders use the expression "scientific development" (kexue fazhan) they usually refer to a predefined set of "scientific" results to be achieved, rather than to the means-scientific, evidence-based methods-to achieve these results. Results which are to a large extent related to goals of environmental and economic sustainability, and social stability. The political language somehow affects the very definition of science (kexue) and scientific research. Not much seems to have changed since the early years of the communist rule, when according to Perry Link "kexue sometimes meant little more or less than 'good' or 'politically correct' [ ... ] a sentence like ni zhege kanfa bu kexue 'this view of yours is unscientific' did not have to refer to [ ... ] any claim that the scientific method had been properly applied" ([107], p. 269; see also [108]). Such an attitude 
facilitates phenomena of data manipulation, aimed at making reality look the way it has been planned, or, in other terms, politically "appropriate" [109].

\section{Environmental Monitoring and Current Political Trends}

Bureaucratic, institutional, economic, political, and ideological factors introduced above exert their influence simultaneously, albeit to different extents. In a polity which is increasingly pluralized and yet not democratic, as the one depicted by fragmented authoritarianism (cf. Section 2), information over the state of the environment can become instrumental in bargaining processes occurring among different actors, both at administrative and policymaking levels. Broadly speaking, these processes appear to be mostly of centrifugal nature, related to the pursuit of particular interests by different actors, not necessarily in line with the declared objectives of the political power. This is the case of manipulation and omissions by local officials and companies. On the other hand, centripetal dynamics can be triggered when issues perceived as threatening the overall stability of the political system arise. Typically, concerns over social stability and popular discontent have the effect of aligning the interests of different institutional actors at both ends of the local-central divide, as well as the interests of major companies. This can lead to opaque procedures of environmental monitoring, as in the case of the National Soil Survey (cf. Section 3.3). Ideology can be seen as constitutive of centripetal processes. In the current Chinese context, science is instrumental not only to the goal of advancing knowledge, but also to sustain the ideological structure on which political power is built upon. In such a context, officials, scientists and technicians involved in environmental monitoring may sacrifice accuracy of data when they are not adequately reflecting the political reality of the moment. Against this background, one of the major transformations in recent years has been the widening possibility for public oversight, brought about by a number of factors. The government has improved its transparency: In 2008, the State Council issued China's first Open Government Information Regulations (OGI), mandating the disclosure of information involving citizens' interest. The MEP was the first agency to implement OGI, issuing in May 2009 the "Measures for Open Environmental Information (for Trial Implementation)" [110]. The internet and new media have provided new platforms of communication, significantly improving the accessibility of environmental information [111]. By using newly accessible information, environmental non-governmental organizations (NGOs) have pushed for still greater transparency, thus demonstrating the value of information disclosure in empowering civil society. The possibility of accessing and circulating official environmental monitoring data, as well as data produced by third parties, has increased awareness over the issue of accuracy, exerting a positive pressure on the government to improve environmental monitoring. The Chinese civil society has been actively advocating for data accuracy and transparency: As stated by the world famous environmental activists Ma Jun in an interview released in 2010, "We cannot fight with slogans or poems. We must fight with data" [112]. Significantly, China's Pollution Information Transparency Index (2013-2014) published by the Institute of Public and Environmental Affairs (IPE) directed by the same Mr. Ma, reported an improvement in transparency, although unevenly distributed across China [113,114]. This said, perspectives for a further strengthening of the capacity of the public to oversee data accuracy remain uncertain. While recent history has proven that an informed public and an active civil society could have a precious role in this respect, the attitude of authorities still remains ambiguous when it comes to further promoting the role of the public and its participation. On the one hand, recent government measures confirm the awareness of the Chinese leadership with regards to the positive potential of public oversight in enhancing environmental monitoring and supervision. An example is provided by the general principles of the "Ecological Civilization System Comprehensive Reform Plan", enacted in 2015 by the Central Committee of the CPC and the State Council, which makes an explicit reference to the role of public participation [13]. On the other hand, as discussed in Section 4.2, authorities still heavily curtail circulation of data and information when the latter are detrimental to social and political stability. In short, recognizing the importance of data accuracy does not necessarily imply a vision for a different future of environmental governance. As a matter of fact, leaders generally 
describe the issue in organizational terms, or by making reference to corruption fuelled by particular interests [28,78]. In an article published online in 2013 and titled "National Vertical Management Needed for Environmental Data", the vice-minister of Environmental Protection Wu Xiaoqing and his co-authors described the issue as follows:

Under the pressure of interests [...], both government bodies, companies, organizations and single individuals have a strong tendency to manipulate, either by falsifying or concealing information. Local statistics are managed by local governments, and as such are subject to the interference by local leaders who aspire at better positions. Against such background, it is difficult to ensure accuracy and reliability of data ([28], online).

The article recommends that the central authorities enhance coordination, streamlining reporting systems, strengthening human resources, and cross-checking data provided by local authorities and companies with data gathered by monitoring stations directly operated by central ministries. Beijing's strive to tighten central control was also confirmed by the announcement in March 2016 of a new reform plan for the management of local environmental administrative bodies, aimed at tackling the negative impacts of "local protectionism" in environmental supervision $[23,24]$. The two-year campaign to inspect air quality monitoring launched by the MEP in April 2015 should be seen in the light of this evolving political and institutional background $[27,78,115]$.

\section{Conclusions}

Deng Xiaoping, the chief architect of China's reforms throughout the 1980s and early 1990s, often remarked on the importance of scientific data in informing policymaking. At present, however, assessing to what degree China's environmental monitoring reports are accurate remains an arduous exercise. Despite sustained efforts made by the Chinese government to strengthen environmental governance, inaccuracies in environmental monitoring data are still present. They are caused to a certain extent by institutional, political, and ideological factors. The issue has been recognized by Chinese central authorities, which have recently launched measures to strengthen administrative coordination and restrain the capacity of local authorities to manipulate data. Information disclosure and the promotion of public participation could be an effective way to enhance accuracy of data. However, future perspectives in this regard remain uncertain. The extent to which Beijing's current efforts will be effective in ensuring more accurate environmental monitoring remains an open question and should be subject to future research and inquiry.

Acknowledgments: The research leading to these results has received funding from the Marie Curie IRSES of the European Union's Seventh Framework Programme (FP7/2007-2013) under REA grant agreement no 269327 Acronym of the Project: EPSEI (2011-2015) entitled “Evaluating Policies for Sustainable Energy Investments: Towards an Integrated Approach on National and International Stage", within the results coordinated by gLAWcal-Global Law Initiatives for Sustainable Development (United Kingdom). The author wishes to thank the informants who provided original materials informing this study: their support and insight were fundamental in crafting this work.

Conflicts of Interest: The author declares no conflict of interest.

\section{References and Notes}

1. Tolstoy, L. Anna Karenina; Oxford University Press: Oxford, UK, 1995.

2. EC Joint Research Centre. Environmental Monitoring. Available online: https://ec.europa.eu/jrc/en/ research-topic/environmental-monitoring (accessed on 7 December 2015).

3. Lovett, G.M.; Burns, D.A.; Driscoll, C.T.; Jenkins, J.C.; Mitchell, M.J.; Rustad, L.; Shanley, J.B.; Likens, G.E.; Haeuber, R. Who needs environmental monitoring? Front. Ecol. Environ. 2007, 5, 253-260. [CrossRef]

4. Biber, E. The Challenge of Collecting and Using Environmental Monitoring Data. Ecol. Soc. $2013,18$. [CrossRef]

5. Steiner, A.; Martonakova, H.; Guziova, Z. (Eds.) Environmental Governance Sourcebook; UNDP Regional Bureau for Europe and the Commonwealth of Independent States: Bratislava, Slovakia, 2003. 
6. Joint Committee for Guides in Metrology (JCGM). International Vocabulary of Metrology, 3rd ed.; JCGM: Sèvres Cedex, France, 2012.

7. Ghanem, D.; Zhang, J. 'Efforless Perfection': So Chinese cities manipulate air pollution data? J. Environ. Econ. Manag. 2014, 68, 203-225. [CrossRef]

8. Bourdieu, P. Il Mestiere di Scienziato. Corso al College de France 2000-2011; Feltrinelli: Milano, Italy, 2003.

9. Van Dijik, T.A. Ideology and Discourse. A Multidisciplinary Introduction; Pompeu Fabra University: Barcelona, Spain, 2005.

10. Saich, T. Governance and Politics of China, 3rd ed.; Palgrave \& McMillan: Houndmills, UK, 2011.

11. Lam, W.W. Chinese Politics in the Hu Jintao Era, New Leaders, New Challenges; M.E. Sharpe: New York, NY, USA, 2006.

12. China Daily. Ecological Civilization. China Daily, 24 October 2007. Available online: http://www.chinadaily. com.cn/opinion/2007--10/24/content_6201964.htm (accessed on 26 May 2016).

13. Central Committee of the CPC, State Council. Ecological Civilization System Comprehensive Reform Plan. Available online: http://www.gov.cn/guowuyuan/2015--09/21/content_2936327.htm (accessed on 26 June 2016).

14. PRWeb. China Environmental Monitoring Instrument Market and Industry Size, Share, Growth, Opportunity, Trends and Forecast Report 2013-2015. PRWeb, 21 October 2014. Available online: http:/ /www.prweb.com/ releases/2014/10/prweb12261166.htm (accessed on 7 December 2015).

15. China Daily. China Increasing Investment in Environmental Protection. China Daily, 13 August 2015. Available online: http:/ / europe.chinadaily.com.cn/business/2015--08/13/content_21589192.htm (accessed on 8 August 2016).

16. Julian, Z.; Yan, Y.; Christina, H.; Claire, W. China's Environment. Big Issues, Accelerating Effort, Ample Opportunities. Goldman Sahcs, 13 July 2015. Available online: http://www.goldmansachs. com/our-thinking/pages/interconnected-markets-folder/chinas-environment/report.pdf (accessed on 8 August 2016).

17. Xinhua. China Pays for $\mathrm{PM}_{2.5}$ Monitoring, U.S. Biz Gains. Xinhua, 5 March 2012. Available online: http: //www.china.org.cn/environment/2012--03/05/content_24805519.htm (accessed on 8 August 2016).

18. Daniele, B.; Haiyan, W.; Lisa, P.; Andrea, C.; Elisa, G. Soil environmental management Systems for Contaminated Sites ion China and the EU. Common Challenges and Perspectives for Lesson Drawing. Land Use Policy 2015, 48, 286-298.

19. Yixiang, D.; Daniele, B.; Paolo, F.; Angela, M.; Andrea, C.; Yun, Z.; Antonio, M. China's Water Environmental Management towards Institutional Integration. A Review of Current Progress and Constraints vis-a-vis the European Experience. J. Clean. Prod. 2016, 113, 285-298.

20. Economy, C.E. China's environmental challenge: Political, social and economic implications. Testimony before the Congressional Executive Commission on China Roundtable on the Environment. Council on Foreign Relations, 27 January 2003. Available online: http://www.cfr.org/china/chinas-environmentalchallenge-political-social-economic-implications/p5573 (accessed on 26 June 2016).

21. Mol, A.P.J. Environmental Governance through Information: China and Vietnam. Singap. J. Trop. Geogr. 2009, 30, 114-129. [CrossRef]

22. China Environment News. Deepen the Implementation of Environmental Protection Reform Measures. Huanjing Bao, 26 April 2016. Available online: http://news.xinhuanet.com/politics/2016-04/26/c_ 128933549.htm (accessed on 26 June 2016).

23. Xinhua. China to Complete Environmental Supervision Reform in Two Years. Xinhua, 11 March 2016. Available online: http://news.xinhuanet.com/english/2016--03/11/c_135179328.htm (accessed on 10 June 2016).

24. Huang, Y. Is China Serious About Pollution Control? Councils on Foreign Relations, 20 November 2015. Available online: http://www.cfr.org/china/china-serious-pollution-controls/p37270 (accessed on 20 June 2016).

25. Ge, C.; Weng, Z.; Li, H.; Ha, C. Implication of Administrative Talk to Environmental Supervision in China: A Case Study of Anyang City. Chin. J. Environ. Manag. 2015, 7, 56-60. (In Chinese)

26. China Scholarship Council. Major National Key State Laboratories List. Available online: http://www. csc.edu.cn/uploads/出国/教育部主管国家重点实验室名单.xls (accessed on 30 November 2015). 
27. Xinhua. Environment Ministry Targets Fake Air Quality Data. Xinhua, 1 April 2015. Available online: http://news.xinhuanet.com/english/2015-04/01/c_134117345.htm (accessed on 7 December 2015).

28. Wu, X.; Hong, G.; Liu, Q. National Vertical Management Needed for Environmental Data. Zhongguo fazhan guancha, 19 March 2013. Available online: http://theory.people.com.cn/n/2013/0319/c40531-20836763.html (accessed on 10 June 2015).

29. McGarrity, J. China Promises Crackdown on Fake Air Quality Data. Chinadialogue, 2 April 2015. Available online: https:/ / www.chinadialogue.net/blog/7828-China-promises-crackdown-on-fake-air-quality-data / en (accessed on 10 June 2015).

30. Waggoner, P.E. Forest Inventories. Discrepancies and Uncertainties; Resources for the Future: Washington, DC, USA, 2009.

31. Herbstein, F.H. Crystalline Molecular Complexes and Compounds: Structures and Principles; Oxford University Press: Oxford, UK, 2005; Volume 2.

32. Becker, J.E.; Krumholz, H.M.; Gal, B.; Ross, J.S. Reporting of Results in ClinicalTrials.gov and High-Impact Journals. JAMA 2014, 311, 1063-1065. [CrossRef] [PubMed]

33. Aylward, M.J.; Rogers, T.; Duane, P.G. Inaccuracy in patient handoffs: Discrepancies between resident-generated reports and the medical record. Minn. Med. 2011, 94, 38-41. [PubMed]

34. CPB Netherlands Bureau for Economic Policy Analysis. Modelling the Reporting Discrepancies in Bilateral Data; CPB: Amsterdam, The Netherland, 2007; Available online: http://www.cpb.nl/en/publication/modellingreporting-discrepancies-bilateral-data (accessed on 7 December 2015).

35. Lieberthal, K.G.; Lampton, D.M. (Eds.) Bureaucracy, Politics, and Decision Making in Post-Mao China; University of California Press: Berkeley, CA, USA, 1992.

36. Lieberthal, K.G.; Oksenberg, M. (Eds.) Policy Making in China. Leaders, Structures, and Processes; Princeton University Press: Princeton, NJ, USA, 1988.

37. Mertha, A. "Fragmented Authoritarianism 2.0": Political Pluralization in the Chinese Policy Process. China Q. 2009, 200, 995-1012. [CrossRef]

38. Andrews, S.Q. Inconsistencies in air quality metrics: 'Blue Sky' days and $\mathrm{PM}_{10}$ concentrations in Beijing. Environ. Res. Lett. 2008, 3, 034009. [CrossRef]

39. Andrews, S.Q. Official Air Pollution Data in Beijing Still Failing the Public. China Dialogue, 15 October 2012. Available online: https://www.chinadialogue.net/article/show/single/en/5212-Official-air-pollutiondata-in-Beijing-still-failing-the-public (accessed on 10 June 2015).

40. Chen, Y.; Jin, G.Z.; Kumar, N.; Shi, G. Gaming in Air Pollution Data? Lessons from China. National Bureau of Economic Research Working Paper Series 18729. Available online: http:/ /www.nber.org/papers/w18729. pdf (accessed on 10 June 2015).

41. Cao, J.; Xu, H.; Xu, Q.; Chen, B.; Kan, H. Fine Particulate Matter Constituents and Cardiopulmunary Mortality in a Heavily Polluted Chinese City. Environ. Health Perspect. 2012, 120, 373-378. [CrossRef] [PubMed]

42. Qiuzi, F.; Zhongnan, F.; Boas, S.B.V.; George, J. An Investigation of the Quality of Air Data in Beijing. 2014. Available online: http:/ / are.berkeley.edu/ sberto/BeijingJuly16.pdf (accessed on 10 June 2015).

43. Caixin. Beijing Releases $\mathrm{PM}_{2.5}$ Air Quality Readings. Caixin, 1 January 2012. Available online: http: / /english.caixin.com/2012-01-21/100350762.html (accessed on 9 August 2016).

44. Wentao, W.; Primbs, T.; Tao, S.; Simonich, S.L.M. Atmospheric Particulate Matter Pollution during the 2008 Beijing Olympics. Environ. Sci. Technol. 2009, 43, 5314-5320.

45. Xibuwang (CnWest). Calling into Question the Battle between Officials and Society over Blue Skies Data in Xi'an. In Shanghai Environmental Protection Bureau; 10 August 2012. Available online: http:/ /www.sepb.gov. cn/fa/cms/shhj//shhj5082/shhj2254/2012/08/73871.htm (accessed on 10 June 2015).

46. Huashang Bao. In the Past Ten Years Xi'an $\mathrm{PM}_{2.5}$ Reached Lowest Levels on July, Highest in January. Huashang Bao, 2 July 2014. Available online: http://hsb.hsw.cn/2014--07/02/content_8541815.htm (accessed on 10 August 2016).

47. Department of Environmental Protection of Shaanxi Province. Environmental Report of Shaanxi Province 2009; Department of Environmental Protection of Shaanxi Province: Xi'an, China, 2010. Available online: http://www.shaanxi.gov.cn/0/1/65/365/370/83864.htm (accessed on 10 August 2016).

48. Department of Environmental Protection of Shaanxi Province. Environmental Report of Shaanxi Province 2008; Department of Environmental Protection of Shaanxi Province: Xi'an, China, 2009. Available online: http:/ /www.shaanxi.gov.cn/0/1/65/365/370/67494.htm (accessed on 10 August 2016). 
49. Ministry of Environmental Protection of China. Ambient Air Quality Standards Draft for Suggestions-Explanatory Notes. 2010. Available online: http://www.mep.gov.cn/gkml/hbb/bgth/ 201011/W020101130374443039627.pdf (accessed on 10 August 2016).

50. Xiao, S.; Xu, H.; Zhang, L.; Zhen, Z.; Zhang, G.; Wei, J.; Shen, J.; Yao, D. Variations in Concentrations of Different Size Fractions of Atmospheric Particulate Matter from Jinghe National Climate Reference Observatory in Xi'an, China. J. Earth Environ. 2012, 3, 1085-1090. (In Chinese)

51. Fujikura, R.; Kaneko, S.; Nakayama, H.; Sawazu, N. Coverage and Reliability of Chinese Statistics Regarding Sulfur Dioxide Emissions during the Late 1990s. Environ. Econ. Policy Stud. 2006, 7, 415-434. [CrossRef]

52. Guan, D.; Liu, Z.; Geng, Y.; Lindner, S.; Hubacek, K. The gigatonne gap in China's carbon dioxide inventories. Nat. Clim. Chang. 2012, 2, 672-675. [CrossRef]

53. The World Bank. Addressing China's Water Scarcity; The World Bank: Washington, DC, USA, 2009.

54. Ma, Z. Evaluation of the Implementation of Water Pollution Prevention and Control Plans in China: The Case of Huai River Basin; The World Bank: Washington, DC, USA, 2006; Available online: http:/ / documents.worldbank.org/curated/en/824051468018234962/Evaluation-of-the-implementationof-water-pollution-prevention-and-control-plans-in-China-the-case-of-Huai-River-Basin (accessed on 31 December 2016).

55. Qin, L. China Needs Consistent Data on Water Pollution If Promised Improvements Are to Be Met. China Dialogue, 18 May 2016. Available online: https://www.chinadialogue.net/article/show/single/ en/8922-Clear-as-mud-how-poor-data-is-thwarting-China-s-water-clean-up (accessed on 9 August 2016).

56. Ministry of Environmental Protection of China. 2011 National Coastal Environmental Quality Report; Ministry of Environmental Protection of China: Beijing, China, 2011. Available online: http://jcs.mep.gov.cn/hjzl/ jagb/2011jagb/ (accessed on 9 August 2014).

57. State Oceanic Administration of China. 2011 Coastal Environmental Quality Report; State Oceanic Administration of China: Beijing, China, 2012. Available online: http://www.coi.gov.cn/gongbao/huanjing/ 201207/t20120709_23185.html (accessed on 9 August 2014).

58. China Water Risk. Are the Data Real? China Water Risk, 9 July 2014. Available online: http:/ / chinawaterrisk. org/resources/analysis-reviews/pollution-is-the-data-real/ (accessed on 1 August 2014).

59. International Business Times. 50 Percent of Water In China May Be Unsafe To Drink. International Business Times, 17 May 2012. Available online: http:/ / www.ibtimes.com/50-percent-water-china-may-be-unsafedrink-698930 (accessed on 10 June 2015).

60. Jing, G.; Hongqiao, L. The Dirty Truth about Water Quality. Caixin Online, 7 May 2012. Available online: http:/ / english.caixin.com/2012-05-07/100387511.html (accessed on 10 June 2015).

61. Xinhua. China Focus: Soil pollution data remains secret, stirs public concern. Xinhua, 9 May 2013. Available online: http://news.xinhuanet.com/english/china/2013--05/09/c_124689362.htm (accessed on 8 August 2013).

62. Teng, Y.; Wu, J.; Lu, S.; Wang, Y.; Jiao, X.; Song, L. Soil and soil environmental quality monitoring in China: A review. Environ. Int. 2014, 69, 177-199. [CrossRef] [PubMed]

63. Wei, B.; Yang, L. A Review of Heavy Metal Contaminations in Urban Soils, Urban Road Dusts and Agricultural Soils from China. Microchem. J. 2010, 94, 99-107. [CrossRef]

64. Meng, A. Heavy Metal pollution in Hunan soil exceeds China's limits by 1500 times. South China Morning Post, 2 December 2014. Available online: http://www.scmp.com/news/china/article/1653877/heavymetal-pollution-hunan-soil-exceeds-chinas-limits-1500-times (accessed on 10 June 2015).

65. China Environment Chamber of Commerce. Strengthening Environmental Management of Contaminated Sites Is an Extremely Urgent Matter. China Environment Chamber of Commerce, 25 April 2014. Available online: http://www.cecc-china.org/detail/19702.html (accessed on 13 April 2015).

66. Bradsher, K. China Asks Other Nations Not to Release Its Air Data. New York Times, 5 June 2012. Available online: http:/ /www.nytimes.com/2012/06/06/world/asia/china-asks-embassies-to-stop-measuring-airpollution.html?_r=0 (accessed on 11 August 2016).

67. Tsai, L. Quantitative Research and Issues of Political Sensitivity in Rural China. In Contemporary Chinese Politics. New Sources, Methods, and Field Strategies; Carlson, A., Gallagher, M.E., Lieberthal, K., Manion, M., Eds.; Cambridge University Press: Cambridge, MA, USA, 2010; pp. 246-265.

68. Cai, Y. Between State and Peasant: Local Cadres and Statistical Reporting in Rural China. China Q. 2000, 163, 783-805. [CrossRef] 
69. Koch-Weser, I. The Reliability of China's Economic Data: An Analysis of National Output; U.S.-China Economic and Security Review Commission Staff Research Project; U.S.-China Economic and Security Review Commission: Washington, DC, USA, 2013.

70. Marinaccio, J. Power and Control of the Chinese Communist Party: An Introduction to China's Cadre Management; Passerino Editore: Gaeta, Italy, 2016.

71. Jing, W.; Yongheng, D.; Jun, H.; Randall, M.; Bernard, Y. Incentives and Outcomes: China's Environmental Policy. Available online: http:/ / www.ires.nus.edu.sg/workingpapers/IRES2013-004.pdf (accessed on 20 June 2016).

72. Chung, C.K.L. Upscaling in Progress: The Reinvention of Urban Planning as an Apparatus of Environmental Governance in China. In Population Mobility, Urban Planning and Management in China; Springer: Heidelberg, Germany; New York, NY, USA, 2015; pp. 171-187.

73. Asia-Europe Meeting (ASEM). ASEM Seminar on Sustainable Management of Water Resources in the Context of Urbanization-Changsha Declaration. Available online: http:/ /www.aseminfoboard.org/documents / asem-seminar-sustainable-management-water-resources-context-urbanisation-changsha (accessed on 11 June 2016).

74. Wuxi City Small Leading Group for the Planning and Construction of Lihu City. Unveiling the Beauty of Lihu Lake. Wuxi Well on Its Way towards Ecological Wellbeing; Phoenix Press Group and Phoenix Publishing House: Wuxi, China, 2007.

75. Economy, E. The River Runs Black: The Environmental Challenge to China's Future; Cornell University Press: Ithaca, NY, USA, 2010.

76. Ma, X.; Ortolano, L. Environmental Regulation in China: Institutions, Enforcement, and Compliance; Rowman and Littlefield: Lanham, MD, USA; Oxford, UK, 2000.

77. Van Rooij, B. Implementation of Chinese Environmental Law: Regular Enforcement and Political Campaigns. Dev. Chang. 2006, 37, 57-74. [CrossRef]

78. CCTV. China to Set up Vertical System to Reduce Local Government Interference in Environment Protection. CCTV. 21 January 2016. Available online: http://newscontent.cctv.com/NewJsp/news.jsp?fileId=338000 (accessed on 9 August 2016).

79. Informant Interview \#0430, 2014 (collected by the author).

80. Informant Interview \#0715a, 2013 (collected by the author).

81. Key Informant Interview \#0315, 2014 (collected by the author).

82. Kostka, G.; Mol Arthur, P.J. Implementation and Participation in China's Local Environmental Politics: Challenges and Innovations. J. Environ. Policy Plan. 2013, 15, 3-16. [CrossRef]

83. Informant Interview \#0610, 2014 (collected by the author).

84. Public Statement \#0109, 2012 (collected by the author).

85. Liu, C. Peking University Report Says Government Is Lying about Air Pollution Problem. The Nanfang, 27 April 2015. Available online: https://thenanfang.com/bju-report-refutes-official-stance-beijing-airpollution/ (accessed on 10 June 2015).

86. BBC News. China Takes under the Dome Anti-Pollution Film Offline. BBC News, 7 March 2015. Available online: http:/ / www.bbc.com/news/world-asia-31778115 (accessed on 10 June 2015).

87. Kotska, G. Barriers to the Implementation of Environmental Policies at the Local Level in China. World Bank Policy Research Working Paper 7016. Available online: http:/ / documents.worldbank.org/curated/ en/102001468220778402/pdf/WPS7016.pdf (accessed on 17 August 2016).

88. Zhang, Z. Programs, Prices and Policies towards Energy Conservation and Environmental Quality in China; FEEM Fondazione Eni Enrico Mattei Research Paper Series No 60.2014; FEEM: Milan, Italy, 2014.

89. David, S.; Kathy, C. False Emissions Reporting Undermines China's Pollution Fight. Reuters, 17 January 2016. Available online: http://www.reuters.com/article/us-china-power-emissions-idUSKCNOUVOXS (accessed on 15 August 2016).

90. Reuters. China Environment Bureau Says Coca-Cola Bottling Plant Falsified Pollution Data. Reuters, 22 October 2015. Available online: http://www.reuters.com/article/us-coca-cola-chinaidUSKCNOSGOLL20151022 (accessed on 15 August 2016).

91. Informant Interview \#0613, 2015 (collected by the author).

92. Key Informant Interview \#0401, 2014 (collected by the author).

93. Barry, N. SASAC and Rising Corporate Power in China. China Leadership Monitor, 12 March 2008. 
94. Economy, E. Environmental Enforcement in China. In China's Environment and the Challenge of Sustainable Development; Kristen, A.D., Ed.; M.E. Sharpe: Armonk, NY, USA, 2005; pp. 102-120.

95. Brodsgaard, K.E. Cadre and Personnel Management in the CPC. China Int. J. 2012, 10, 69-83.

96. Informant Interview \#0809, 2013 (collected by the author).

97. Moorman, J.L.; Zhang, G. Promoting and Strengthening Public Participation in China's Environmental Impact Assessment Process: Comparing China's EIA Law and U.S. NEPA. Vt. J. Environ. Law 2007, 8, 282-335.

98. Informant Interview \#1102, 2014 (collected by the author).

99. Bao, X. China's EIA Industry Rife with Fraud. China Dialogue, 3 November 2014. Available online: https: //www.chinadialogue.net/article/show/single/en/7449-China-s-EIA-industry-rife-with-fraud- (accessed on 10 August 2015).

100. Qie, J. MEP Has Named 15 Companies Guilty of Producing Fraudulent Environmental Impact Assessments: The Participants to the Survey Had Not Filled in the Investigation Form. Legal Daily, 27 November 2015. Available online: http://www.thepaper.cn/newsDetail_forward_1401898 (accessed on 10 August 2015).

101. Spence, J.D. The Search for Modern China; W.W. Norton \& Company: New York, NY, USA, 1999.

102. Elman, B.A. A Cultural History of Modern Science in China; Harvard University Press: Cambridge, MA, USA, 2006.

103. Deng, X. Deng Xiaoping Wenxuan—Di Er Juan; Renmin Chubanshe: Beijing, China, 1993; Volume II.

104. Nature. The Future of Chinese Research-Editorial. Nature 2016, 534. [CrossRef]

105. Greenhalgh, S. Just One Child. Science and Policy in Deng's China; University of California Press: Berkeley, CA, USA; Los Angeles, CA, USA, 2008.

106. Informant Interview \#0715b, 2013 (collected by the author).

107. Link, P. An Anatomy of Chinese; Harvard University Press: Cambridge, MA, USA, 2013.

108. Schoenals, M. Doing Things with Words in Chinese Politics: Five Studies; Center for Chinese Studies: Berkeley, CA, USA, 1992.

109. Daniele, B. Politicizzazione Della Ricerca Orientata Alle Politiche Pubbliche Nella Repubblica Popolare Cinese. In Proceedings of the XIV Conference of the Italian Association of Chinese Studies, Procida, Italy, 19-21 September 2013; Available online: http://www.aisc-org.it/AISC_Atti_XIV_Convegno_con_segnalibri. pdf (accessed on 10 June 2015).

110. Tod, K.; Rongkun, L. Taking the Pulse: The One-Year Anniversary of China's Open Government Information Measures. Wilson Center, 7 July 2011. Available online: https://www.wilsoncenter.org/publication/ taking-the-pulse-the-one-year-anniversary-chinas-open-government-information-measures (accessed on 17 August 2016).

111. Yang, G. The Internet and Emerging Civil Society in China. In Debating Political Reform in China: Rule of Law vs. Democratization; Zhao, S., Ed.; M.E. Sharpe: Armonk, NY, USA, 2006.

112. Larson, C. In China, a New Transparency on Government Pollution Data. Yale Environment 360, 20 December 2010. Available online: http://e360.yale.edu/featurein_china_a_new_transparency_on_government_ pollution_data/2352/ (accessed on 10 June 2015).

113. National Resources Defence Council (NRDC); Istitute of Public and Environmental Affairs (IPE). Cutting through the Fog with China's First Pollution Information Transparency Index (PITI); NRDC-IPE: New York, NY, USA; Beijing, China, 2009; Available online: https://www.nrdc.org/international/piti/files/chinapiti.pdf (accessed on 10 June 2015).

114. China Water Risk. Environmental Transparency in 120 Chinese Cities Revealed. China Water Risk, 9 June 2014. Available online: http://chinawaterrisk.org/notices/environmental-transparency-in-120-chinesecities-revealed/ (accessed on 10 June 2015).

115. Reuters. China to Toughen Inspection on Air Quality Data: Xinhua. Reuters, 1 April 2015. Available online: http:/ /www.reuters.com/article/2015/04/02/us-china-pollution-idUSKBN0MT06H20150402 (accessed on 10 June 2015).

(C) 2017 by the author. Licensee MDPI, Basel, Switzerland. This article is an open access article distributed under the terms and conditions of the Creative Commons Attribution (CC BY) license (http:/ / creativecommons.org/licenses/by/4.0/). 